\title{
The Critical Success Measuring Criteria for B2B E-commerce Systems in Medical Supply Chain
}

\author{
Chengbo Wang, \\ Zhaofang Mao, \\ John Johansen, \\ James T. Luxhoj, \\ James O'kane, \\ Jun Wang, \\ Liguo Wang \\ and Xuezhong Chen,
}

\begin{abstract}
The paper presents an exploratory investigation to determine and prioritise the critical success measuring criteria, which can measure and guide the successful application and performance improvement of business to business (B2B) e-commerce system (BBECS) in a medical supply chain's selling and buying functions, in the context of global business expansion.

The research reveals that the buying and the selling functions have different prioritisations on majority of the determined critical success measuring criteria. These criteria are categorised into three Critical Success Measuring Criteria Groups (CSMCGs), for the selling and the buying functions respectively, guiding medical supply chain members in harnessing the full advantage of a BBECS.

For the selling function, the top critical success measuring criteria are: integrating information searching/transmission and application processes, ensuring the reliability and timeliness of technical support, ensuring recognition and acceptance of e-commerce processes, displaying the organization's business focus and product/service provisions online, securing a large scale/amount of business transactions, adjusting production outputs and inventory levels and having more registered users than competitors do. The top critical success measuring criteria for the buying function are: securing the establishment of business relationships between businesses, displaying the measures ensuring mutual trust and cooperation online, ensuring employees' recognition of the benefit of e-commerce in increasing revenue, ensuring the contribution to the development and realisation of corporate strategy, achieving cost reduction for the organization, making the purchase of famous brand products available/doable, securing a large scale/amount of business transactions, and ensuring the attainability of products/services at a lower price.
\end{abstract}


Key words: B2B E-commerce system, Success measuring criteria, Performance, Prioritisation, China

\section{Introduction}

As noted by many researchers (e.g., Perrigot and Pénard, 2013; Fernie et al., 2010; Pramatari et al., 2009; Luk, 2009) and demonstrated by the calls for journal/conference papers on this topic (CASCI, 2014; IJCSI, 2014), the implementation of e-commerce systems to increase the business processes' efficacy is a crucial element of business strategies.

The healthcare sector is an important part of the economy, and the implementation of ecommerce system in its supply chain is also a popular practice (Smith and Correa, 2005; Cullen and Taylor, 2009) in both developing and developed countries. Within the healthcare supply chain, the medical supply and distribution system between member organizations [business to business (B2B)] plays a key role to ensure the quality and timeliness of healthcare provision. The successful application of e-commerce system in a medical supply chain enhances the performance of the supply chain members and improves their capability to fulfil customers' demands (Lin et al., 2010; HPN, 2003; Anonymous 2005). However, the use of e-commerce in B2B medical supply chains has not realised its full potential (Bhakoo and Chan, 2011). Similarly, research on this topic is rather insufficient for informing and instructing the businesses' operations as illustrated by calls of journals for special issue (SIG-Health, 2012; IJCSI, 2014), particularly with regard to the criteria that can be used to measure and guide the successful application of e-commerce (Lin et al., 2010) for the selling and the buying functions of medical supply chain members (Cullen and Taylor, 2009; Dey and Nath, 2013; Smith and Correa, 2005).

The aforementioned highlights the importance of determining a set of critical success measuring criteria, which can be used to judge the efficacy of medical supply chain members' B2B e-commerce system (BBECS) and to guide their implementation and realise performance improvement.

As a rapidly developing country and one of the drivers of the current global economy, China has been developing and implementing e-commerce rapidly in all of its business sectors (Yang et al., 2011), including the healthcare sector (MOFCOM, 2011). The Chinese government has 
provided substantial support for e-commerce application (NDRC and SCIO, 2007; Chang and Liu, 2006; Jin et al., 2008; CMIC, 2012), with a result that the application of e-commerce in Chinese businesses has been increasing at a double-figure rate (CERC, 2011; Zheng, 2012; iResearch, 2009; Wei, 2012). Thus, China was selected as the general setting for the investigation on account of: 1) the continuous improvement and development of the ecommerce market in recent years; 2) the increased number of Chinese medical supply chain members implementing BBECS in their business operations; 3) the substantial support and encouragement from the government on applying e-commerce systems in businesses, especially for medical supply chains where BBECS is the main form of e-business operations; 4) and China has the largest population in the world and is a large marketplace for foreign medical organizations to expand their businesses to, where e-commerce can enhance and increase their market presence.

In summary, a comprehensive study of the application characteristics of Chinese medical supply chain business to business e-commerce systems (MS-BBECS) is necessary. Focusing on Chinese medical supply chains, the authors in this paper provide and prioritise a set of critical success measuring criteria that could be employed to facilitate the decision-making in the application of MS-BBECSs in medical supply chains, ensure performance improvements and guide the strategic development of medical organizations wishing to enter or currently operating in Chinese and other global marketplaces.

The paper is structured as this: the next section provides the literature review for the general research context containing the candidate (primary) critical success measuring criteria for the MS-BBECS application, followed by the introduction of the research methodology; subsequently, the research conduct and findings for the finalised critical success measuring criteria, their prioritisation and empirical applicability are presented; conclusions, implications, limitations and future research finalise the paper.

\section{Literature review for the background context of the research}

2.1 Business to Business e-commerce and its application in Chinese medical supply chains

E-commerce refers to activities and processes that use information technology based on the internet or other networks for businesses to conduct the communications and transactions with their customers, suppliers, etc. 
A Business to Business e-commerce system (BBECS) conducts business activities between the businesses connected through the internet or other commercial or not-for-profit network systems. BBECSs have obvious advantages and can bring substantial benefit to business transaction processes and activities, compared to conventional approaches (Bourlakis and Bourlakis, 2006; Jin et al., 2008; CMIC, 2012). With a BBECS, the communication and transaction processes can be completed speedily online: from initial contact, to bidding, negotiation, ordering, delivery management, etc. as well as to after sales service. A BBECS helps the supply chain members reduce the costs associated with the conventional procedures and increase the efficiency and effectiveness through reducing the processing time and errors (CMIC, 2012; Chang and Liu, 2006); especially in the context of globalisation, business interactions often occur between enterprises in different countries/regions, the convenience and extendibility of a BBECS can accelerate the speed of business processes/activities and facilitate the businesses' long-term development to ensure their position in international marketplaces (Zheng, 2012).

Besides the effective and efficient support to buying and selling activities, a BBECS also functions as a solid platform for the establishment and maintenance of strategic partnerships among supply chain members. As argued by researchers (e.g., Wang et al., 2010; Christopher, 2005; Kotzab et al., 2008), the contemporary market competition is not between individual enterprises, rather it is between supply chains. By setting up partnerships, organizations group themselves to increase their competitiveness, which can be better facilitated and achieved through a BBECS. BBECSs enhance the efficacy of information flow, strengthen vertical and horizontal business collaborations and ensure the partner organizations to achieve a stronger market position and higher performance.

Thus, with regard to supply chain members, the aim of implementing a BBECS is not only for short-term benefit, but also for long-term sustainable development. This has been recognised by many businesses and it is reflected in their corporate strategies (Zheng, 2012; Smith and Correa, 2005; Jin et al., 2008; CMIC, 2012).

The implementation of BBECSs in Chinese enterprises continues to grow (Chang and Liu, 2006; Hu, 2011; Lv, 2010; Jin et al., 2008; Zhang, 2011) with an annual increase rate of more than 10\% in recent years (CERC, 2011; Zheng, 2012; Wei, 2012). The increase has been particularly notable in medical supply chains where BBECS is the main form of e-business operations (Hu, 2011). Both internal and external factors have driven this phenomenon (NDRC and SCIO, 2007; Chang and Liu, 2006; Jin et al., 2008; CMIC, 2012). These include: 1) enhanced recognition by the businesses of the benefits of applying BBECSs; 2) improved 
utilisation of resources facilitated by BBECSs in supply chain member organizations, and 3) governmental support to e-businesses, e.g., governmental BBECS platform with standardized processes accessible to both the buying and the selling functions of medical supply chain members.

For ensuring the medical supply chain members' application efficacy of a BBECS, it is very important to identify and determine the critical success criteria, which can be used to measure the performance and guide the implementation of MS-BBECSs and lead to performance improvement (Ram et al., 2013); the critical success measuring criteria will not only facilitate the Chinese medical supply chain members in applying e-commerce systems and gaining benefits, but also guide/inform international medical organizations wishing to enter or already operating in Chinese or other global marketplaces.

\subsection{Critical success measuring criteria for MS-BBECS application}

The major actors within a medical supply chain are the manufacturers, wholesalers, retailers, hospitals and other healthcare organizations and end consumers. However, as the main form of e-business in the Chinese medical supply chain is BBECS (Hu, 2011), thus the individual consumers were excluded from the present study. Inspired by the approach from Cullen and Taylor (2009), for the convenience and accuracy of data collection, the participating organizations in the study were categorised into a selling function group and a buying function group. Herein, the selling function group includes manufacturers and wholesalers (Chinese Economy Net, 2012; MOFCOM, 2011; Wang, 2000), and the buying function group includes retailers, hospitals and other healthcare providers.

Drawing from the earlier research that of Jin and Kim (2010), Cullen and Taylor (2009), Fathian et al. (2008), Stefani and Xenos (2008) and Ramanathan (2012), among others, and the selection/findings in a focus group session, Tables 1-1 and 1-2 list the candidate (primary) critical success measuring criteria; these criteria were also used as the survey questionnaire content. The majority of the criteria apply to both the selling and the buying functions; however, as demonstrated in Table 1-2, there are still a few criteria different between the two functions respectively, to address their different business emphasises. The survey questions in this research were worded with the content and meaning the same as the criteria in Tables 1-1 and 12.

Table 1-1. The primary critical success measuring criteria for MS-BBECS 


\begin{tabular}{|c|c|c|}
\hline $\begin{array}{l}\text { Criterion } \\
\text { no. }\end{array}$ & Criterion's content & Sources for support of the proposition \\
\hline 1 & $\begin{array}{l}\text { System and information security can be } \\
\text { guaranteed }\end{array}$ & $\begin{array}{l}\text { Jin and Kim, 2010; Fathian et al., 2008; Stefani and } \\
\text { Xenos, 2008; Ramanathan, 2012; Ramanathan, 2010; } \\
\text { Pramatari et al., 2009; Lai and Yang, 2009; Weathers } \\
\text { and Makienko, 2006; Coltman et al., 2007; Sung, 2006; } \\
\text { Lee and Kozar, 2006 }\end{array}$ \\
\hline 2 & $\begin{array}{l}\text { E-commerce systems can provide timely, } \\
\text { effective, accurate and detailed } \\
\text { information }\end{array}$ & $\begin{array}{l}\text { Stefani and Xenos, 2008; Pramatari et al., 2009; Sebora } \\
\text { et al. 2009; Weathers and Makienko, 2006; Wu et al., } \\
\text { 2011; Lee and Kozar, } 2006\end{array}$ \\
\hline 3 & Easy use of the system is secured & $\begin{array}{l}\text { Jin and Kim, 2010; Stefani and Xenos, 2008; Pramatari } \\
\text { et al., 2009; Lai and Yang, 2009; Sebora et al., 2009; } \\
\text { Weathers and Makienko, 2006; Sung, 2006; Lee and } \\
\text { Kozar, } 2006\end{array}$ \\
\hline 4 & $\begin{array}{l}\text { The stability of the system and of the } \\
\text { network is secured }\end{array}$ & Sung, 2006; Hu, 2011; Chang and Liu, 2006 \\
\hline 5 & $\begin{array}{l}\text { Trust and confidence have been } \\
\text { established between enterprises doing } \\
\text { business using the system }\end{array}$ & $\begin{array}{l}\text { Jin and Kim, 2010; Stefani and Xenos, 2008; Lee and } \\
\text { Rao, 2009; Pramatari et al., 2009; Lai and Yang, 2009; } \\
\text { Weathers and Makienko, 2006; Sung, 2006; Lee and } \\
\text { Kozar, 2006; Wu et al., } 2011\end{array}$ \\
\hline 6 & $\begin{array}{l}\text { Products/services have been reasonably } \\
\text { priced and accurately displayed on-line } \\
\text { at the company's website }\end{array}$ & $\begin{array}{l}\text { Stefani and Xenos, 2008; Lee and Rao, 2009; } \\
\text { Ramanathan, 2010; Lai and Yang, 2009; Eikebrokk } \\
\text { and Olsen, 2007; Weathers and Makienko, 2006; Sung, } \\
\text { 2006; Lee and Kozar, } 2006\end{array}$ \\
\hline 7 & $\begin{array}{l}\text { A variety of products/services is } \\
\text { available }\end{array}$ & $\begin{array}{l}\text { Sung, 2006; Chang and Liu, 2006; Zheng, 2012; } \\
\text { CMIC, } 2012\end{array}$ \\
\hline 8 & $\begin{array}{l}\text { The quality of the information flow can } \\
\text { be ensured (e.g., accuracy of delivery } \\
\text { time, stock levels and out of stock items) }\end{array}$ & $\begin{array}{l}\text { Jin and Kim, 2010; Stefani and Xenos, 2008; Pramatari } \\
\text { et al., 2009; Lai and Yang, 2009; Sebora et al., 2009; } \\
\text { Lee and Kozar, 2006; Wu et al., } 2011\end{array}$ \\
\hline 9 & $\begin{array}{l}\text { The reputation/credibility of the } \\
\text { enterprise and its related websites is } \\
\text { maintained }\end{array}$ & Lee and Kozar, 2006; Wu et al., 2004 \\
\hline 10 & $\begin{array}{l}\text { Advertisements for relevant } \\
\text { products/services are conducted on } \\
\text { website }\end{array}$ & Sung, 2006; Hu, 2011; Zhang, 2011; Jin et al., 2008 \\
\hline 11 & $\begin{array}{l}\text { Information searching, transmission and } \\
\text { application processes are highly } \\
\text { integrated. The process is paperless, with } \\
\text { no need for printing documents unless } \\
\text { specially requested }\end{array}$ & $\begin{array}{l}\text { Pramatari et al., 2009; Lai and Yang, 2009; Wang and } \\
\text { Lin, 2009; Eikebrokk and Olsen, 2007; Sung, } 2006\end{array}$ \\
\hline 12 & $\begin{array}{l}\text { The system makes the company more } \\
\text { efficient compared with conducting } \\
\text { business using other channels }\end{array}$ & $\begin{array}{l}\text { Jin and Kim, 2010; Stefani and Xenos, 2008; Lee and } \\
\text { Rao, 2009; Ramanathan, 2010; Lai and Yang, 2009; } \\
\text { Sung, 2006; Lee and Kozar, } 2006\end{array}$ \\
\hline 13 & $\begin{array}{l}\text { Continuity of hardware/software usage } \\
\text { for the websites is ensured, no need for } \\
\text { frequent reinstallation and upgrading }\end{array}$ & $\begin{array}{l}\text { Cullen and Taylor, 2009; supported by a consensus } \\
\text { among the experts in the focus group }\end{array}$ \\
\hline 14 & $\begin{array}{l}\text { The software is easy to upgrade when } \\
\text { upgrades are required }\end{array}$ & $\begin{array}{l}\text { Suggested to be part of the questionnaire content by } \\
\text { experts in the focus group }\end{array}$ \\
\hline 15 & $\begin{array}{l}\text { Reliability and timeliness of the technical } \\
\text { support to the system are ensured }\end{array}$ & $\begin{array}{l}\text { Fathian et al., 2008; Sebora et al., 2009; Sung, 2006; } \\
\text { Lee and Kozar, } 2006\end{array}$ \\
\hline 16 & $\begin{array}{l}\text { Cost reduction for communications and } \\
\text { business transactions with other related } \\
\text { enterprises is secured, compared with } \\
\text { doing business offline }\end{array}$ & $\begin{array}{l}\text { Jin and Kim, 2010; Lee and Rao, 2009; Sebora et al., } \\
\text { 2009; Eikebrokk and Olsen, 2007; Wu et al., 2011; Lee } \\
\text { and Kozar, } 2006\end{array}$ \\
\hline 17 & $\begin{array}{l}\text { Recognition and acceptance of e- } \\
\text { commerce process/application by the }\end{array}$ & $\begin{array}{l}\text { Fathian et al., 2008; Stefani and Xenos, 2008; Lee and } \\
\text { Rao, 2009; Pramatari et al., 2009; Sebora et al., 2009; }\end{array}$ \\
\hline
\end{tabular}




\begin{tabular}{|c|c|c|}
\hline & $\begin{array}{l}\text { relevant selling/buying functions of the } \\
\text { supply chain are ensured }\end{array}$ & Sung, 2006; Lee and Kozar, 2006; Wang and Lin, 2009 \\
\hline 18 & $\begin{array}{l}\text { Standardisation of e-commerce system } \\
\text { are realised }\end{array}$ & $\begin{array}{l}\text { Fathian et al., 2008; Stefani and Xenos, 2008; Sebora } \\
\text { et al., } 2009\end{array}$ \\
\hline 19 & $\begin{array}{l}\text { Number of business users of the system } \\
\text { is large }\end{array}$ & $\begin{array}{l}\text { Lee and Kozar, 2006; Jin and Kim, 2010; Lee and Rao, } \\
\text { 2009; Pramatari et al., } 2009\end{array}$ \\
\hline 20 & $\begin{array}{l}\text { A business relationship is established } \\
\text { among the businesses within the supply } \\
\text { chain network }\end{array}$ & $\begin{array}{l}\text { Jin and Kim, 2010; Fathian, et al., 2008; Lai and Yang, } \\
\text { 2009; Wang and Lin, } 2009\end{array}$ \\
\hline 21 & $\begin{array}{l}\text { Solid business agreements are } \\
\text { established between related enterprises }\end{array}$ & Evans and Wurster, 1999; Cullen and Taylor, 2009 \\
\hline 22 & $\begin{array}{l}\text { Information on the relevant market and } \\
\text { products/services is displayed online }\end{array}$ & $\begin{array}{l}\text { Jin and Kim, 2010; Stefani and Xenos, 2008; Pramatari } \\
\text { et al., 2009; Weathers and Makienko, 2006; Sung, } \\
2006\end{array}$ \\
\hline 23 & $\begin{array}{l}\text { Measures ensuring mutual trust and } \\
\text { cooperation are displayed online at the } \\
\text { company's website }\end{array}$ & $\begin{array}{l}\text { Jin and Kim, 2010, and supported by a consensus } \\
\text { among the focus group }\end{array}$ \\
\hline 24 & $\begin{array}{l}\text { All levels of management support the use } \\
\text { of e-commerce system }\end{array}$ & $\begin{array}{l}\text { Fathian et al., 2008; Lai and Yang, 2009; Wang and } \\
\text { Lin, } 2009\end{array}$ \\
\hline 25 & $\begin{array}{l}\text { Employees recognise the benefit of } \\
\text { increasing revenue through the e- } \\
\text { commerce system }\end{array}$ & $\begin{array}{l}\text { Pramatari et al., 2009; Lai and Yang, 2009; Coltman et } \\
\text { al., 2007; Sung, 2006; Lee and Kozar, } 2006\end{array}$ \\
\hline 26 & $\begin{array}{l}\text { Relevant laws/regulations concerning e- } \\
\text { commerce are made aware of to all users }\end{array}$ & Fathian et al., 2008; Sebora et al., 2009 \\
\hline 27 & $\begin{array}{l}\text { The E-commerce system makes positive } \\
\text { contribution to the development and } \\
\text { realisation of corporate strategy }\end{array}$ & $\begin{array}{l}\text { Jin and Kim, 2010; Fathian, et al., 2008; Pramatari et } \\
\text { al., 2009; Sebora et al., 2009; Wang and Lin, 2009; } \\
\text { Eikebrokk and Olsen, 2007; Coltman et al., 2007; Lee } \\
\text { and Kozar, 2006; Sung, 2006 }\end{array}$ \\
\hline 28 & $\begin{array}{l}\text { The organisation's cost reduction is } \\
\text { achieved through the use of e-commerce } \\
\text { system }\end{array}$ & $\begin{array}{l}\text { Jin and Kim, 2010; Fathian et al., 2008; Pramatari et } \\
\text { al., 2009; Sebora et al., 2009; Eikebrokk and Olsen, } \\
\text { 2007; Lee and Kozar, 2006; Wu et al., 2011 }\end{array}$ \\
\hline 29 & $\begin{array}{l}\text { The organization's business focus and } \\
\text { products/services provisions are fully } \\
\text { displayed online at the company's } \\
\text { website }\end{array}$ & $\begin{array}{l}\text { Jin and Kim, 2010; Eikebrokk and Olsen, 2007; Lee } \\
\text { and Kozar, 2006; Wu et al., } 2011\end{array}$ \\
\hline 30 & $\begin{array}{l}\text { Sale/purchase of well-known products } \\
\text { online are made available to e-commerce } \\
\text { user organisations }\end{array}$ & Jin and Kim, 2010; Sung, 2006 \\
\hline 31 & $\begin{array}{l}\text { Renowned business partners' names are } \\
\text { displayed online at the company's } \\
\text { website to increase the organisation's } \\
\text { reputation }\end{array}$ & Eikebrokk and Olsen, 2007 \\
\hline 32 & $\begin{array}{l}\text { Large scale/amount of business } \\
\text { transactions are facilitated and secured } \\
\text { by the usage of e-commerce system }\end{array}$ & $\begin{array}{l}\text { Jin and Kim, 2010; Pramatari et al., 2009; Lai and } \\
\text { Yang, 2009; Wu et al., } 2011\end{array}$ \\
\hline 33 & $\begin{array}{l}\text { Production outputs and inventory levels } \\
\text { can be adjusted through online } \\
\text { information sharing }\end{array}$ & Fathian et al., 2008; Pramatari et al., 2009 \\
\hline 36 & $\begin{array}{l}\text { Effectiveness and completeness of } \\
\text { logistics distribution system are secured } \\
\text { by e-commerce system }\end{array}$ & Jin and Kim, 2010; Pramatari et al., 2009 \\
\hline 37 & $\begin{array}{l}\text { The system is supported by relevant } \\
\text { laws, regulations }\end{array}$ & $\begin{array}{l}\text { Fathian et al., 2008; Lee and Rao, 2009; Sebora et al., } \\
\text { 2009; Wang and Lin, } 2009\end{array}$ \\
\hline
\end{tabular}


Table 1-2. The primary critical success measuring criteria for MS-BBECS for the selling/buying functions respectively

\begin{tabular}{|l|l|l|}
\hline $\begin{array}{l}\text { Criterion } \\
\text { No. }\end{array}$ & For the selling function & Source for support of the proposition \\
\hline 34 & $\begin{array}{l}\text { The number of the registered users at } \\
\text { the organisation's homepage is higher } \\
\text { than that of the competitors }\end{array}$ & Suggestion provided by experts in the focus group \\
\hline 35 & $\begin{array}{l}\text { The level and remit of additional } \\
\text { services by the supplier on the products } \\
\text { technical advice, after sales service, } \\
\text { etc.) are satisfactory to customers }\end{array}$ & Ramanathan, 2011; Eikebrokk and Olsen, 2007 \\
\hline \hline $\begin{array}{l}\text { Criterion } \\
\text { No. }\end{array}$ & For the buying function & Source for support of the proposition \\
\hline 34 & $\begin{array}{l}\text { Obtaining products/services at a lower } \\
\text { price through the e-commerce system } \\
\text { is ensured }\end{array}$ & $\begin{array}{l}\text { CBIN, 2012; supported by a consensus among the } \\
\text { experts in the focus group }\end{array}$ \\
\hline 35 & $\begin{array}{l}\text { Registering on the website is easy } \\
\text { The features and functionality of the } \\
\text { purchased products can be easily } \\
\text { understood }\end{array}$ & Suggestion provided by experts in the focus group \\
\hline 38 & Zhang (2011); Jin, et al. (2008); Hu, 2011 \\
\hline
\end{tabular}

\section{Methodology}

\subsection{Research strategy}

This research was performed through three stages.

In Stage 1, based on the published research in the relevant fields, the authors conducted an extensive literature search of the measuring criteria on the success of e-commerce application for both the selling and the buying functions, with a particular focus on the medical supply chain. At this stage, the success measuring criteria were identified and summarised for later focus group and survey investigation to seek further enrichment and confirmation as well as to finalise and prioritise the most critical ones.

The Stage 2 research activities were conducted in three steps:

In Step 1, a focus group was organised with two aims: 1) to further seek the confirmation from the field experts of the meaningfulness of the research topic; 2) to primarily determine the candidate critical success measuring criteria (Tables 1-1 and 1-2) based on the literature findings and field experts' knowledge, and also to develop the survey questionnaire with these criteria as the content. The questionnaire is used to obtain the medical supply chain members' judgements on the importance levels of the criteria and the performance levels against their focused business aspects from the dimensions of the selling and the buying functions; the survey data will then be 
used to consolidate the candidate critical success measuring criteria through principal component analysis (PCA) into a smaller set of the most critical criteria for efficacy of their practical application; and also to prioritise these criteria through importance-performance analysis (IPA) for a more effective guidance to develop strategies to improve the performance of their focused business aspects.

The content validity of the research was also verified by another group of experts in this step.

In Step 2, the survey questionnaire was pilot tested and refined.

In Step 3, all aforementioned types of organizations in the medical supply chain in three regions in the central and eastern parts with representative levels of e-commerce usage (CMIC, 2012; EEO, 2010; Yang, et al., 2011; Huang, eta al., 2012) were contacted beforehand to invite and encourage their participation in the research. Then the distribution/reminding and receipt/collection of questionnaires to/from those participating organizations were performed; analysis on the collected data was conducted through descriptive statistical analysis, PCA and IPA.

Stage 3 contains two steps:

In Step 1, alongside the outcome from Stage 2, the prioritised success measuring criteria for a MS-BBECS' application and performance improvement were test applied.

In Step 2, based on the analysis of the above findings, concluding remarks were presented.

\subsection{Brief introduction of the methods used for the research}

\subsubsection{Focus group and survey}

The focus group technique is a very effective tool for obtaining consensual viewpoints in a short time on certain topics from a group of field experts (Evason and Whittington, 1997; Krueger, 1994; Crowley and Gilreath, 2002). The focus group in this research was conducted in China with participants consisting of three academics in the relevant fields, three practical professionals in the selling function and three in the buying function medical organizations. From the focus group, firstly, the participants reached a consensus that strongly resonates to and endorses the literature findings of the importance, significance and practical demand of a set of criteria guiding the success of e-commerce system's application in real world businesses in medical supply chains; secondly, the measuring criteria obtained from the literature review were scrutinized, enriched and primarily approved (Tables 1-1 and 1-2): with 37 criteria for the selling function and 38 criteria for the buying function as candidate critical success measuring criteria to be further examined by other methods. 
Survey as a well known research instrument, is applied in various disciplines to collect data for obtaining understanding and generalising insights (e.g., Yang, 2012; Pentina et al. 2013; Abareshia and Mollaa, 2013; Lee et al., 2011; Kwok, 1995; Shim et al., 2007; van der Vaart and van Donk, 2008; Gralla et al., 2013). Within this research, the survey samples were members of Chinese medical supply chains, including manufacturers, wholesalers, retailers, hospitals and other healthcare service providers with e-commerce system applied in their business operations. These participating organizations locate in the regions with representative level of B2B ecommerce system usage; their answers to the research questions can be considered representing the current situation of BBECS application (CMIC, 2012; EEO, 2010; Yang et al., 2011; Huang et al., 2012), based on their e-commerce activities through the collective medical purchase platform (General Office of the State Council, 2010).

\subsubsection{Principal component analysis (PCA)}

To further prune the number of success measuring criteria to distil the most critical ones for more focused subsequent investigation and more effective/efficient practical implementation, a PCA was applied. PCA is an often used analysis technique (e.g., Esmaeili and Shokoohi, 2011; Goldstein and Naor, 2005; Tomes and $\mathrm{Ng}, 1995)$ to reduce the number of variables/attributes attached to certain issues, based on the obtained corresponding data.

\subsubsection{Importance-performance analysis (IPA) for prioritisation}

IPA (Martilla and James, 1977) is a technique facilitating the exploration on business operations' strengths and weaknesses, by comparing the recognition on the importance of the attributes and evaluation on the operations' performance in terms of those attributes. IPA provides in-depth insights and understanding of the most critical elements that impact performance.

In this research, following a five-point scale (from 5-Very important/Highly complying with the criterion to 1-Very unimportant/Highly not-complying with the criterion), in the questionnaire the research participants were required to evaluate the critical success measuring criteria in two perspectives: 1) how important did participants believe the individual success measuring criterion is; 2) how well did participants believe their e-commerce system has been performing against the corresponding criterion. The importance/performance evaluation against any criterion from any individual buyers/sellers is based on the perception of their concrete situation, which can vary for different organizations. 
Through IPA analysis, the most critical success measuring criteria were confirmed and prioritised.

\subsection{Validity and reliability}

\subsubsection{Validation of the research}

The measuring criteria (Tables 1-1 and 1-2) were developed through the focus group based on the information summarised from published literature, and these criteria were used as the questionnaire content. In the questionnaire, the research participants were also given space and encouraged to provide additional criteria and comments they deemed necessary. The designed questionnaire was then examined by an additional focus group with two academics, two professionals in the buying function and two professionals in the selling function in the medical supply chain, for attesting the research content validity. After the content validity was confirmed by the experts, a pilot study was conducted with three professionals in charge of the selling function and three professionals in charge of the buying function. Following the piloting feedback, the authors made a minor adjustment on the questionnaire layout and a few questions' wording; then the larger scale survey investigation was performed.

Based on the factor analysis on the collected data, the individual variables' (components') loadings to the respective four quadrants (factors) determined by IPA are well above the threshold level of 0.3 (Pastor, 2013) respectively for the selling function (factor loadings range from 0.5 to 0.94 ) and the buying function (factor loadings range from 0.51 to 0.91 ). Thereby, the construct validity was confirmed.

To ensure the external validity, the participating organizations were selected from the regions with the representative BBECS performance status (CMIC, 2012; EEO, 2010), and they were actively engaged in the use of MS-BBECS in their business operations.

\subsubsection{Reliability of the survey instrument}

Researchers frequently use Cronbach's $\alpha$ to check the reliability (e.g., Wu et al., 2004; Wee and Quazi, 2005). Normally, Cronbach's $\alpha$ value of 0.7 or higher is an indication of acceptable reliability (Wortzel, 1979; Nunnally, 1978).

To triangulate/enhance the reliability understanding, the authors used Spearman-Brown prophecy calculation (e.g., Engs, 1996) as a supplementary method.

The Cronbach's $\alpha$ and the Spearman-Brown coefficient values for the reliability test of this research are presented in Table 2, corresponding to the relevant sample groups. 
Table 2. Reliability test result

\begin{tabular}{|l|l|l|}
\hline Sample groups & Cronbach's $\boldsymbol{\alpha}$ & $\begin{array}{l}\text { Spearman- } \\
\text { Brown prophecy }\end{array}$ \\
\hline Selling function & 0.936 & 0.966 \\
\hline Buying function & 0.919 & 0.942 \\
\hline
\end{tabular}

The participating organizations in both the buying function and the selling function groups include small, medium and large-sized enterprises. Through a similarity test of their viewpoints on the questions, there is no significant difference between the different sized organizations in the respective selling and buying function groups, as illustrated in Table 3. Thus the selling function and the buying function groups can be analysed as two "wholes".

Table 3. Similarity test result

\begin{tabular}{|c|c|}
\hline Sample groups & ANOVA score range (at 95\% confidence level) \\
\hline Selling function & From 0.09 to 0.96 \\
\hline Buying function & From 0.08 to 0.97 \\
\hline
\end{tabular}

In summary, the survey data in this research are reliable for drawing the findings.

\section{Research conduct and findings}

\subsection{Research conduct}

In the aforementioned regions, according to the data from the local government agencies and authority websites (e.g., HSIIN, 2012; China Commerce Net, 2012), there are in total 1029 medical supply chain organizations that can be categorised into selling function group, and 819 that can be categorised into buying function group. To ensure an effective data collection, these organizations were contacted beforehand. Although this was time consuming, it meant that the questionnaire was distributed (personal delivery or mail) only to those organizations engaged in MS-BBECSs and had agreed to participate; two days after the distribution, a further contact of reminding (and answering to any questions from the participants) was conducted with the organizations having been sent the questionnaire. This strategy ensured the timeliness of the questionnaire completion and response rate as well as the completeness of the answers to the 
questions. A total of $98 \%$ of the distributed questionnaires were returned via mail or collected by the research team within one week of them being distributed. Communication with the nonresponsive organizations informed that either these organizations changed their mind and withdrew from the participation, or they only recently implemented the e-commerce system and did not have usage experience to answer the questions. Of the returned questionnaires, $96 \%$ were complete and usable. The profile of the participating organizations is summarised in Table 4. Only three of the returned questionnaires contained a few additional proposed criteria; however, given the diversified foci and the lack of consensus of these suggestions, these criteria are not included in the analysis.

Table 4. Profile summary of the participating organizations (having returned completed questionnaires)

\begin{tabular}{|c|c|c|c|c|}
\hline Functions & $\begin{array}{l}\text { Large-s } \\
\text { enterpr }\end{array}$ & $\begin{array}{r}\text { Medium-s } \\
\text { enterpri }\end{array}$ & $\begin{array}{r}\text { Small-si } \\
\text { enterpr }\end{array}$ & Total \\
\hline \multirow{2}{*}{ Selling funct } & 26 & 59 & 39 & 124 \\
\hline & $20.97 \%$ & $47.58 \%$ & $31.45 \%$ & $100 \%$ \\
\hline \multirow{2}{*}{ Buying funct } & 20 & 61 & 29 & 110 \\
\hline & $18.18 \%$ & $55.45 \%$ & $26.36 \%$ & $100 \%$ \\
\hline
\end{tabular}

4.2 Finalised critical success measuring criteria through PCA

PCA then pruned the number of the candidate critical success measuring criteria and further confirmed them. Table 5 (corresponding communality values) and Table 6 (criteria's content) present the finalised criteria after the PCA reduction (calculated using SPSS Statistics Version 20).

Table 5. Finalised criteria after PCA [communality values (higher than 0.5) in brackets] 


\begin{tabular}{|c|c|c|c|c|c|c|c|}
\hline $\begin{array}{l}\text { Organization } \\
\text { function }\end{array}$ & \multicolumn{3}{|c|}{$\begin{array}{l}\text { Criteria No. corresponding to } \\
\text { Table } 1-1,1-2\end{array}$} & \multirow[b]{2}{*}{\begin{tabular}{|l|}
$\begin{array}{l}\text { Organization } \\
\text { function }\end{array}$ \\
\\
Buying function \\
\end{tabular}} & \multicolumn{3}{|c|}{$\begin{array}{l}\text { Criteria No. corresponding to } \\
\text { Table } 1-1,1-2\end{array}$} \\
\hline $\begin{array}{l}\text { Selling } \\
\text { function }\end{array}$ & $\begin{array}{l}3(0.73), \\
7(0.86), \\
10(0.824), \\
13(0.761), \\
16(0.542), \\
19(0.865), \\
23(0.644), \\
26(0.775), \\
29(0.672), \\
32(0.853), \\
35(0.935),\end{array}$ & $\begin{array}{l}5(0.915), \\
8(0.668), \\
11(0.587), \\
14(0.768), \\
17(0.621), \\
20(0.758), \\
24(0.613), \\
27(0.662), \\
30(0.858), \\
33(0.684), \\
36(0.88),\end{array}$ & $\begin{array}{r}6(0.702), \\
9(0.627), \\
12(0.501), \\
15(0.668), \\
18(0.881), \\
22(0.642), \\
25(0.648), \\
28(0.786), \\
31(0.91), \\
34(0.564), \\
37(0.795)\end{array}$ & & $\begin{array}{l}2(0.548), \\
5(0.933), \\
8(0.527), \\
12(0.769), \\
15(0.577), \\
18(0.848), \\
21(0.598), \\
24(0.649), \\
27(0.668), \\
30(0.647), \\
33(0.794), \\
36(0.718),\end{array}$ & $\begin{array}{c}3(0.523), \\
6(0.858), \\
10(0.834), \\
13(0.717), \\
16(0.753), \\
19(0.514), \\
22(0.805), \\
25(0.58), \\
28(0.75), \\
31(0.913), \\
34(0.613), \\
37(0.84),\end{array}$ & $\begin{array}{r}4(0.791), \\
7(0.529), \\
11(0.699), \\
14(0.889), \\
17(0.617), \\
20(0.642), \\
23(0.718), \\
26(0.823), \\
29(0.752), \\
32(0.759), \\
35(0.914), \\
38(0.551)\end{array}$ \\
\hline
\end{tabular}

Table 6. Content of the finalised criteria

\begin{tabular}{|c|c|c|}
\hline $\begin{array}{l}\text { Function } \\
\text { focus }\end{array}$ & $\begin{array}{l}\text { Criteria } \\
\text { No. }\end{array}$ & Criteria content \\
\hline $\begin{array}{l}\text { For both } \\
\text { the } \\
\text { Selling } \\
\text { function } \\
\text { and the } \\
\text { Buying } \\
\text { function }\end{array}$ & $\begin{array}{l}18 \\
19 \\
20\end{array}$ & 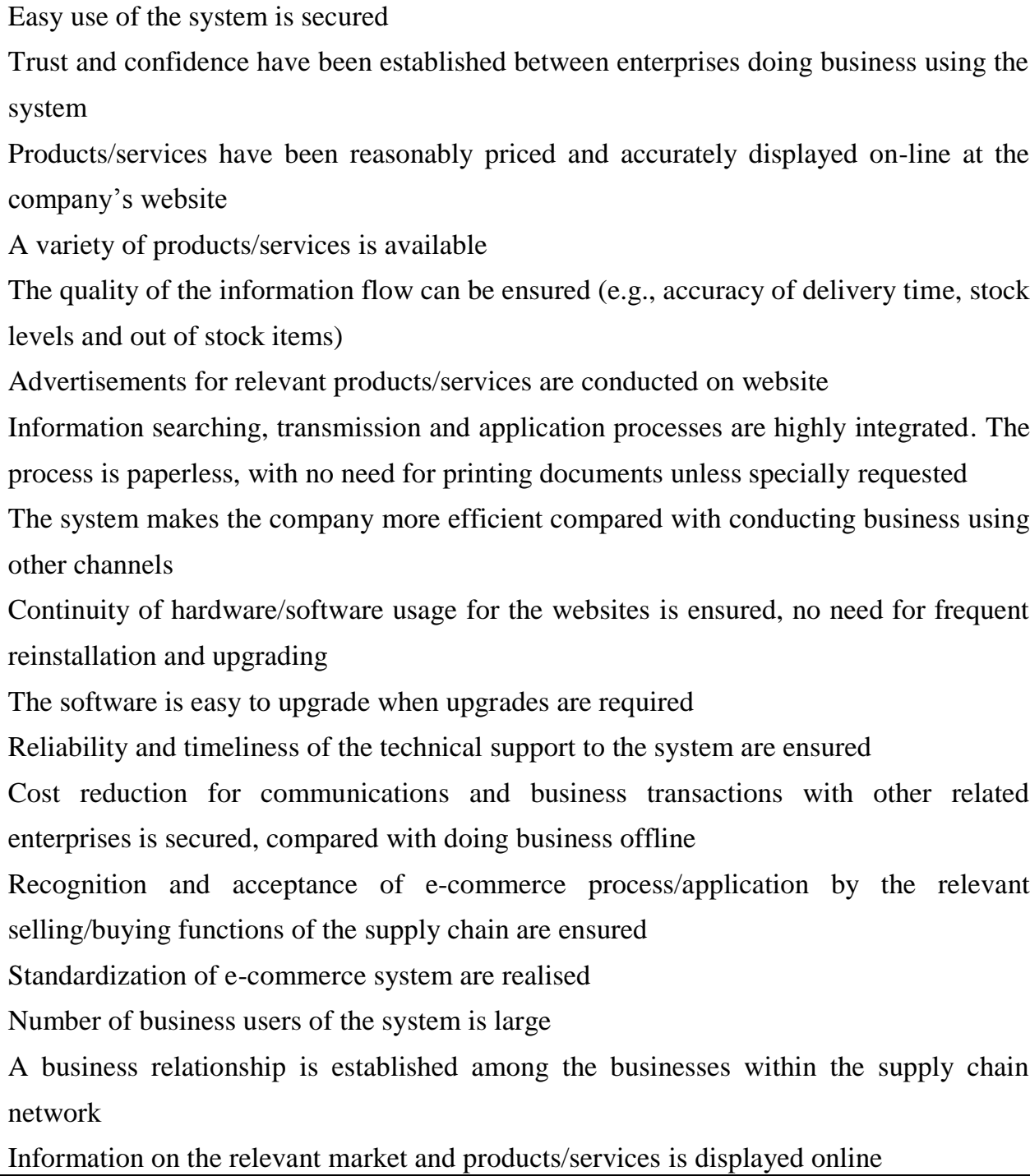 \\
\hline
\end{tabular}




\begin{tabular}{|c|c|c|}
\hline & $\begin{array}{l}24 \\
25 \\
26 \\
27\end{array}$ & $\begin{array}{l}\text { Measures ensuring mutual trust and cooperation are displayed online at the company's } \\
\text { website } \\
\text { All levels of management support to the usage of e-commerce system is ensured } \\
\text { Employees recognise the benefit of increasing revenue through the e-commerce system } \\
\text { Relevant laws/regulations concerning e-commerce are made aware of to all users } \\
\text { The E-commerce system makes positive contribution to the development and realisation } \\
\text { of corporate strategy } \\
\text { The organisation's cost reduction is achieved through the use of e-commerce system } \\
\text { The organization's business focus and products/services provisions are fully displayed } \\
\text { online at the company's website } \\
\text { Sale/purchase of well-known products online are made available to e-commerce user } \\
\text { organisations } \\
\text { Renowned business partners' names are displayed online at the company's website to } \\
\text { increase the organisation's reputation } \\
\text { Large scale/amount of business transactions are facilitated and secured by the usage of e- } \\
\text { commerce system } \\
\text { Production outputs and inventory levels can be adjusted through online information } \\
\text { sharing } \\
\text { Effectiveness and completeness of logistics distribution system are secured by e- } \\
\text { commerce system } \\
\text { The system is supported by relevant laws, regulations }\end{array}$ \\
\hline $\begin{array}{l}\text { For the } \\
\text { Selling } \\
\text { Function }\end{array}$ & $\begin{array}{l}9 \\
34\end{array}$ & $\begin{array}{l}\text { The reputation/credibility of the enterprise and its related websites is maintained } \\
\text { The number of the registered users at the organisation's homepage is higher than that of } \\
\text { the competitors } \\
\text { The level and remit of additional services by the supplier on the products (technical } \\
\text { advice, after sales service, etc.) are satisfactory to customers }\end{array}$ \\
\hline $\begin{array}{l}\text { For the } \\
\text { Buying } \\
\text { function }\end{array}$ & $\begin{array}{l}21 \\
34 \\
35 \\
38\end{array}$ & $\begin{array}{l}\text { E-commerce systems can provide timely, effective, accurate and detailed information } \\
\text { The stability of the system and of the network is secured } \\
\text { Solid business agreements are established between related enterprises } \\
\text { Obtaining products/services at a lower price through the e-commerce system is ensured } \\
\text { Registering on the website is easy } \\
\text { The features and functionality of the purchased products can be easily understood }\end{array}$ \\
\hline
\end{tabular}

To prioritise the above finalised critical success measuring criteria and to guide the ecommerce practice, IPA was performed.

\subsection{Results based on IPA}

The IPA was conducted firstly for the selling function and then the buying function. Figures 1 and 2 depict the findings from IPA on the criteria for the selling function and the buying 
function groups respectively, using the average importance and performance ratings as the demarcation lines.

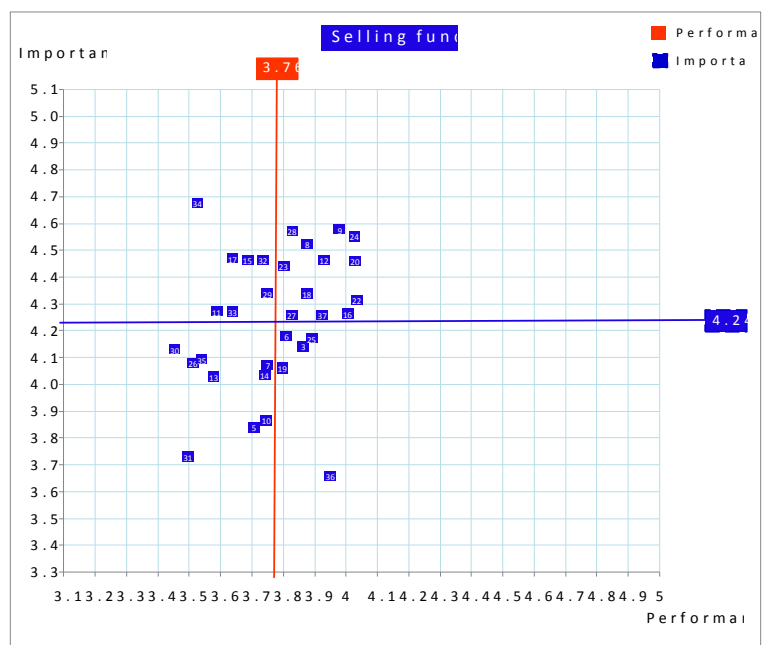

Figure 1. IPA analysis outcome on the criteria for the selling function

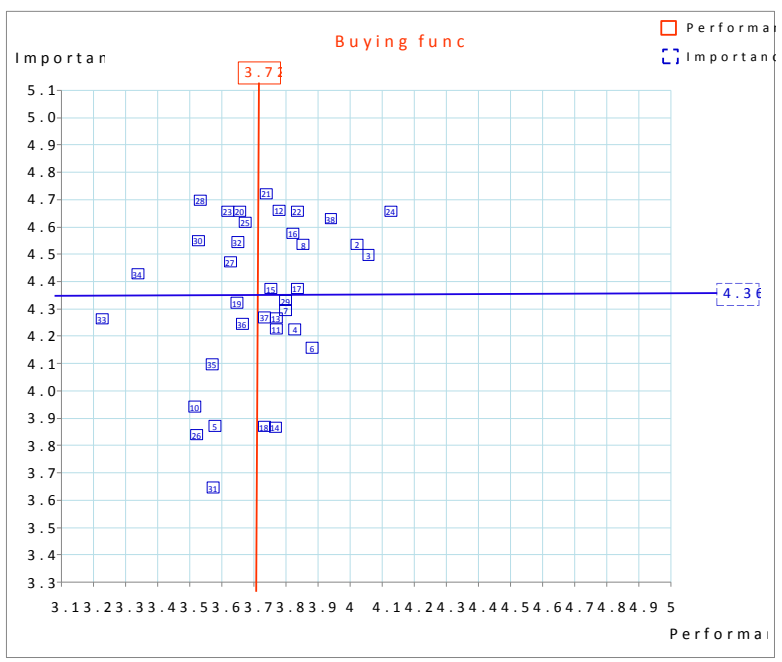

Figure 2. IPA analysis outcome on the criteria for the buying function

From Figures 1 and 2, one can see that corresponding to the coordinates of importance and performance levels, following the same classification style, for both the buying function and the selling function respectively, the critical measuring criteria fall into four quadrants; however, the majority criteria in each individual quadrants for the selling function are different from those in the same quadrants for the buying function.

To facilitate medical supply chain members applying these critical criteria effectively and efficiently in practice, based on a set of combinations of different levels of importance and performance to the criteria, the authors have ranked them into three Critical Success Measuring 
Criteria Groups (CSMCGs), which can guide the buying and selling functions in the application and performance improvement of MS-BBECSs. Table 7 summarises the classification of the criteria and their corresponding quadrants and CSMCGs for the selling and the buying functions respectively, following the ranked order of CSMCGs.

Table 7. Criteria No. and corresponding quadrant/CSMCG

\begin{tabular}{|c|c|c|c|}
\hline Quadrants & $\begin{array}{l}\text { Selling function (Criterion } \\
\text { No.) }\end{array}$ & $\begin{array}{l}\text { Buying function (Criterion } \\
\text { No.) }\end{array}$ & $\begin{array}{l}\text { CSMCG } \\
\text { rank }\end{array}$ \\
\hline $\begin{array}{l}\text { Quadrant } 2 \text { - High importance } \\
\text { level \& Low performance level }\end{array}$ & $11,15,17,29,32,33,34$ & $20,23,25,27,28,30,32,34$ & $1^{\text {st }} \mathrm{CSMCG}$ \\
\hline $\begin{array}{l}\text { Quadrant } 1 \text { - High importance } \\
\text { level \& High performance level }\end{array}$ & $\begin{array}{l}8,9,12,16,18,20,22,23, \\
24,27,28,37\end{array}$ & $\begin{array}{l}2,3,8,12,15,16,17,21, \\
22,24,38\end{array}$ & \multirow{2}{*}{$\begin{array}{l}2^{\text {nd }} \\
\text { CSMCG }\end{array}$} \\
\hline $\begin{array}{l}\text { Quadrant } 4 \text { - Low importance } \\
\text { level \& Low performance level }\end{array}$ & $\begin{array}{l}5,7,10,13,14,26,30,31, \\
35\end{array}$ & $5,10,19,26,31,33,35,36$ & \\
\hline $\begin{array}{l}\text { Quadrant } 3 \text { - Low importance } \\
\text { level \& High performance level }\end{array}$ & $3,6,19,25,36$ & $\begin{array}{l}\text { criteria } 4,6,7,11,13,14, \\
18,29,37\end{array}$ & $3^{\text {rd }} \mathrm{CSMCG}$ \\
\hline
\end{tabular}

Medical supply chain members can now use the information in Tables 6 and 7 to identify and prioritise the weaknesses/strengths in their e-commerce application processes, and to allocate relevant resources for improving the focused weaknesses, and consequentially to enhance the efficacy of their MS-BBECSs, especially when they have limited resources and need to prioritise their allocation, something that is a common phenomenon in business practice.

Applicable to both the selling function and the buying function, the criteria that need the most attention and resources' allocation for performance improvement of their focused business aspects are those belonging to Quadrant 2 (with High importance level \& Low performance level), these criteria are ranked as the $1^{\text {st }} \mathrm{CSMCG}$; if resources are available, a reasonable amount of effort should be allocated to maintain/improve the corresponding business aspects' performance level of the criteria in Quadrant 1 (with High importance level \& High performance level) and Quadrant 4 (with Low importance level \& Low performance level), these two quadrants' criteria are ranked as the $2^{\text {nd }}$ CSMCG; no immediate further effort is needed to improve the corresponding business aspects' performance for Quadrant 3 criteria (with Low importance level \& High performance level), and this quadrant's criteria are ranked as the $3^{\text {rd }}$ CSMCG. 
The authors also performed an analysis to firstly identify the criteria deemed critical by both the two functions collectively and then to determine their prioritisation. The result is summarised in Table 8 (excluding the criteria in Table 1-2 for one of the two functions only).

Table 8. Criteria prioritisation for both functions collectively

\begin{tabular}{|l|l|l|}
\hline Importance \& performance level & Criterion No. & CSMCG rank \\
\hline $\begin{array}{l}\text { High importance level \& Low } \\
\text { performance level }\end{array}$ & 32 & $1^{\text {st }}$ CSMCG \\
\hline $\begin{array}{l}\text { High importance level \& High } \\
\text { performance level }\end{array}$ & $8,12,16,22,24$ & \multirow{2}{}{$2^{\text {nd }}$ CSMCG } \\
\hline $\begin{array}{l}\text { Low importance level \& Low } \\
\text { performance level }\end{array}$ & $5,10,26,31$ & \\
\hline $\begin{array}{l}\text { Low importance level \& High } \\
\text { performance level }\end{array}$ & 6 & $3^{\text {rd }}$ CSMCG \\
\hline
\end{tabular}

As Table 8 has demonstrated that the amount of criteria with collective prioritisation consensus from both functions are rather small; this phenomenon indicates a lack of similarity in the prioritisation of the critical success measuring criteria between the buying and selling function. Namely, there is a low level of consensus between the buying function and the selling function organizations on these criteria's importance and/or performance. It is difficult for the buying function and the selling function to share a same set of approaches corresponding to the criteria's prioritisation order for ensuring the MS-BBECS' successful application.

Identified by the research, the reasons for the above situation include: Firstly, the buying function and the selling function have different business objectives/preferences for the application of the e-commerce systems, and this phenomenon leads to the different emphasis (perception of importance) levels on the corresponding business aspects pertaining to the criteria. Secondly, compared with the MS-BBECS' application in the developed countries, the MSBBECS' application started later in China and is still evolving, with a consequence of that the challenges facing the buying and the selling functions are not always the same; such a situation results to the individual MS-BBECS members' diversified attention and resources allocated to the respective criterion focused business aspect. Thirdly, some organizations have not trained their employees sufficiently to ensure their awareness and effective use of the e-commerce system's advantages. Fourthly, the diversified levels of resources and attention allocated by different organizations to the business aspect corresponding to the individual criterion, as well 
as the further impacts of the employees' awareness extent of MS-BBECS and the efficacy level of its use in different organizations, consequentially lead to the rather salient difference between the buying and the selling functions' general viewpoints on the performance and importance levels of the respective criteria. Fifthly, the authors also deem that the experience level of the businesses' MS-BBECS application can impact their perception of the importance of the various criteria as well as the effort needed to maintain/improve the performance of these criteria focused business aspects. Sixthly, the different external competitive environments faced by the buying function and the selling function organizations can substantially affect their perception and/or preference of the criteria's performance/importance levels.

In view of the aforementioned, it is necessary to have a future longitudinal research focusing on the possible change of the prioritisation on the criteria and the underlying reasons from both the buying function and the selling function dimensions, to add more insights and provide further in-depth understanding to the findings of this research.

\subsection{The practical test application of the CSMCGs}

To test the CSMCGs' applicability, they (and their content criteria's rating scale from the IPA analysis) were provided to two medical manufacturers and one wholesalers focusing on the ecommerce selling function, and two retailers focusing on the buying function for test application.

The assessments after one year of the test application are very positive as reported in Table 9, demonstrating the CSMCGs' usefulness to the businesses. The test application evidenced that the CSMCGs and their component criteria can efficiently and effectively facilitate an MSBBECS' performance improvement targets'/action plans' determination and resources' allocation, thereby ensure the smooth and fruitful e-commerce application within a medical supply chain.

Table 9, Assessment on the applicability of CSMCGs

\begin{tabular}{|l|c|c|}
\hline \multirow{2}{*}{ Assessment aspect } & \multicolumn{2}{|l|}{$\begin{array}{l}\text { Average score (1-Very low to 5-Very } \\
\text { high) }\end{array}$} \\
\cline { 2 - 3 } & Selling function & Buying function \\
\hline Efficiency & 4.3 & 4.5 \\
\hline Effectiveness & 4.7 & 4 \\
\hline
\end{tabular}




\section{Concluding remarks}

\subsection{Conclusions}

Based on the research findings, for a MS-BBECS' selling and buying functions as a whole, there is less consensus on the candidate critical e-commerce success measuring criteria's applicability. This situation leads to the impossibility of a shared strategy, which can be collectively used and appropriate for both the selling and the buying functions in the successful application of e-commerce systems.

Nevertheless, for the selling and the buying functions respectively, as illustrated by Table 6 , the majority of the candidate criteria in Tables 1-1 and 1-2 are confirmed as effective in measuring and guiding the successful application of MS-BBECSs. However, the buying function and the selling function have different prioritisations on majority of the critical success measuring criteria. Thus, an effective approach to ensure the successful MS-BBECS' usage is to decide and allocate efforts and resources separately corresponding to the order of the prioritised critical success measuring criteria in Table 7 for the selling and the buying functions respectively. This research has ranked these criteria into three Critical Success Measuring Criteria Groups $\left(1^{\text {st }}\right.$ CSMCG, $2^{\text {nd }}$ CSMCG and $3^{\text {rd }}$ CSMCG) for the selling function and the buying function respectively, to facilitate their MS-BBECSs' application.

For the selling function, the most crucial criteria $\left(1^{\text {st }} \mathrm{CSMCG}\right)$, which require the largest effort and attention to improve their focused business aspects' performance and to enhance a MSBBECS' operations efficacy, include:

- Information searching, transmission and application process being highly integrated;

- Reliability and timeliness of the technical support to the system being ensured;

- Recognition and acceptance towards e-commerce process from the relevant selling/buying functions of the supply chain being ensured;

- The organization's business focus and product/service provisions being fully displayed online;

- Large scale/amount of business transactions being secured by the usage of the e-commerce system;

- Adjustment of production outputs and inventory levels through online information sharing being realised;

- Registered users' number at the organizations' homepage being larger than that of the competitors. 
For the buying function, the most crucial criteria $\left(1^{\text {st }} \mathrm{CSMCG}\right)$ include:

- The business relationship establishment with the businesses within the supply chain network being secured;

- The measures ensuring mutual trust and cooperation being displayed online;

- Employees having recognized the benefit of increasing revenue through the e-commerce system;

- E-commerce system application ensuring its positive contribution to the development and realisation of the corporate strategy;

- Organisations' cost reduction being achieved through application of the e-commerce system;

- Purchase of renowned brand products online being available/doable;

- Large scale/amount of business transactions being secured by the application of the ecommerce system;

- Obtaining products/services at lower price through the e-commerce system being ensured.

Moreover, this research shows the efficacy of the CSMCGs and their content criteria in supporting MS-BBECSs' successful application and performance improvement in practical businesses.

\subsection{Managerial implications}

The management of the medical supply chain members can implement the CSMCGs by following the prioritised order of the criteria for their MS-BBECSs' application and performance improvement. This enables them to ensure the most appropriate allocation of the required resources for a successful and smooth running of their e-commerce systems, which will contribute to the prosperous and healthy survival of their businesses.

Besides providing guidance to Chinese MS-BBECS members in their successful application of e-commerce systems, the findings can also help foreign medical organizations entering and operating in the healthcare sectors in China and other developing countries to harness the advantages of MS-BBECSs.

\subsection{Theoretical implications}

In addition to providing the medical supply chain members with a set of guiding and measuring criteria and supporting their consolidating and implementing these criteria for continuous e-commerce success, this research contributes to the theoretical knowledge pool on 
the prioritisation and evaluation of the success criteria for B2B medical e-commerce systems' application.

\subsection{Limitations}

As the empirical findings were mainly derived from a Chinese perspective, although they can provide referential guidance to the medical supply chain members entering/operating in other countries for their successful e-commerce application, adjustments on the prioritisation of the criteria and modification on their contents are possible in different contexts. These are the issues to be aware of when the CSMCGs are applied in practice in different countries and are also a topic to be explored in future research. The CSMCGs were only tested among a small number of medical supply chain members, thus the range of their applicability needs to be further examined.

\subsection{Future research}

Based on the research outcome, the following future research suggestions are provided to enrich the obtained findings and develop new insights:

- The CSMCGs could be assessed in more case companies from different countries to determine how they could be adjusted/modified to better facilitate the MS-BBECSs' application in different contexts.

- A follow up project could be performed to include more practical organizations applying B2B e-commerce systems from other supply chains, focusing on a cross-sector comparative analysis on the similarities and differences of the success measuring criteria of BBECSs.

- A longitudinal research could focus on the possible changes of the criteria and their prioritisation as well as the underlying reasons from both the buying function and the selling function dimensions, to enrich the field with more in-depth insights/understandings.

\section{References}

Abareshia, A. and Molla, A. 2013. Greening logistics and its impact on environmental performance: an absorptive capacity perspective, International Journal of Logistics Research and Applications: A Leading Journal of Supply Chain Management, 16(3), 209-226.

Anonymous 2005. Rush promotional campaign was designed to promote physicians, nurses, research, Health Care Strategic Management, 23 (1), 10. 
Bhakoo, V. and Chan, C. 2011. Collaborative implementation of e-business processes within the health-care supply chain: the Monash Pharmacy Project. Supply Chain Management: An International Journal, 16 (3), 184-193.

Bourlakis, M. and Bourlakis, C. 2006. Integrating logistics and information technology strategies for sustainable competitive advantage, Journal of Enterprise Information Management, 19(4), 389-402.

CASCI (2014). [Call for Papers] ICEC 2014: The 16th International Conference on Electronic Commerce 2014, Centre for the Advanced Study of Communities and Information, http://casci.umd.edu/2014/01/30/call-for-papers-icec-2014-the-16th-international-conferenceon-electronic-commerce-2014/ [January].

CBIN, 2012. Review on the E-commerce development in China at the first half in 2012. Chinese Business Information Net, http://www.askci.com/news/201208/22/162530_57.shtml [August 2012].

Chang, F. and Liu, Y. 2006. Scientific selection of buying/selling model for medical enterprises' e-commerce. Chinese Medicine Industry, (2).

China Commerce Net 2012. http://www.sjzp.com/jinan [August 2012].

China e-commerce research centre (CERC) 2011. Monitoring report of first half 2011 Chinese e-commerce market. Baidu Article Storage, http://wenku.baidu.com/view/e9b34ecf da38376baf1faed2. html [August 2012].

Chinese Economy Net 2012. Medial E-businesses influence the medical distribution structure benefiting consumers, online at: http://www.people.com.cn [November].

Christopher, M. 2005. Logistics and supply chain management: creating value-adding networks (3rd ed.). FT Prentice Hall, London.

CMIC 2012. Balance regional development, build up e-commerce with local characteristics. China Market Intelligence Centre, http://www.ccidreport.com/market/article/content/3698/ 201207/ 277364. html [August].

Coltman, T. R., Devinney, T. M. and Midgley, D. F. 2007. e-Business strategy and firm performance: a latent class assessment of the drivers and impediments to success. Journal of Information Technology, 22, 87-101.

Crowley, G. H. and Gilreath, C. L. 2002. Probing user perceptions of service quality: using focus groups to enhance quantitative survey. Performance Measurement and Metrics, 3 (2), 78 84. 
Cullen, A. J. and Taylor, M. 2009. Critical success criteria for B2B e-commerce use within the UK NHS pharmaceutical supply chain. International Journal of Operations \& Production Management, 29(11), 1156-1185.

Dey, D. and Nath, A. 2013. Study on key Issues and Critical Success Factors of e-Supply Chain Management in Health Care Services, International Journal of Advanced Computer Research, 3 (1), 7-13.

Economic Observer (EEO) 2010. Gradual imbalance of the distribution of e-commerce, three major factors impeding its development. The Economic Observer, http://www.eeo.com.cn/ 2010/1009/182242.shtml [August 2012].

Engs, R. C. 1996. Construct validity and re-assessment of the reliability of the HEALTH CONCERN QUESTIONNAIRE. Advances in Health Education/Current Research, (4), Edited by Robert H.L. Feldman and James H. Humphrey, AMS, Press, Inc., New York: 303-313.

Eikebrokk, T. R. and Olsen, D. H. 2007. An empirical investigation of competency factors affecting e-business success in European SMEs. Information \& Management, 44, 364-383.

Esmaeili, A. and Shokoohi, Z. 2011. Assessing the effect of oil price on world food prices: Application of principal component analysis. Energy Policy, 39(2), 1022-1025.

Evans, P. and Wurster, T.S. 1999. Getting real about virtual commerce. Harvard Business Review, November-December, 85-94.

Evason, E. and Whittington, D. 1997. Patients' perceptions of quality in a Northern Ireland hospital trust: a focus group study. International Journal of Health Care Quality Assurance, 10(1), 7-19.

Fathian, M., Akhavan, P. and Hoorali, M. 2008. E-readiness assessment of non-profit ICT SMEs in a developing country: The case of Iran. Technovation, 28, 578-590.

Fernie, J., Sparks, L. and McKinnon, A. C. 2010, Retail logistics in the UK: past, present and future, International Journal of Retail \& Distribution Management, 38(11/12), 894-914.

General Office of the State Council 2010. The notification on issuing the instructive opinion for establishing and standardising medical purchasing mechanism in governmentally run basic medical and health institutions, General Office of the State Council issuing No. 56, Online at [Accessed December 2014]: http://www.gov.cn/zwgk/2010-12/09/content_1761749.htm.

Goldstein, S. M. and Naor, M. 2005. Linking publicness to operations management practices: a study of quality management practices in hospitals. Journal of Operations Management, 23, 209-228. 
Gralla, E., Goentzel, J. and Fine, C. 2013. Assessing trade-offs among multiple objectives for humanitarian aid delivery using expert preferences, Production and Operations Management, forthcoming, doi: 10.1111/poms.12110.

Hangzhou Statistics Investigation Information Net (HSIIN) 2012. Online at [Accessed August 2012]: http://www.hzstats.gov.cn/web.

HPN 2003. Steady progress on e-commerce and supply chain activities, with Charles Saunders, MD, People \& Opinions, Healthcare Purchasing News, December 2003, 50-53.

Hu, H. 2011. China medical e-commerce: predicament and way out. Global Science, Technology and Economy Outlook, http://www.cqvip.com/QK/92892A/201112/40446102.html [August 2012].

Huang, H., Jing, L. and Li, L. 2012. Analysis on the development characteristics of ecommerce at the main regions in China, Science \& Technology and Economy, 25(4), 91-95.

International Journal of Computer Science Issues (IJCSI) 2014. IJCSI Call For Papers 2014/2015, International Journal of Computer Science Issues, http://ijcsi.org/call-for-papers.php [Accessed January].

iResearch 2009. China B2B E-Commerce Research Report 2008-2009, http://wenku.baidu. com/view/11f9760abb68a98271fefa00.html [August 2012].

Jin, B. and Kim, J. 2010. Multichannel versus pure e-tailers in Korea: evaluation of online store attributes and their impacts on e-loyalty. The International Review of Retail, Distribution and Consumer Research 20(2), 217-236.

Jin, P., Liu, J. and Ni, N. 2008. Exploratory analysis on current Chinese medical e-commerce status. Heilongjiang Scientific and Technology Information, 21.

Kotzab, H., Grant, D. B., Teller, C. and Halldorsson, A. 2008. Supply chain management and hyper competition. Logistics Research, 1(1), 12-20.

Krueger, R.A. 1994. Focus Groups: A Practical Guide for Applied Research. Sage, Thousand Oaks, CA.

Kwok, C. C. Y. 1995. International Business Education of the United States in the 1990s: Accredited vs. Nonaccredited Schools. The International Executive, 37(1), 17-34.

Lai, J.-Y. and Yang, C.-C. 2009. Effects of employees' perceived dependability on success of enterprise applications in e-business. Industrial Marketing Management, 38, 263-274.

Lee, J. and Rao, H. R. 2009. Task complexity and different decision criteria for online service acceptance: A comparison of two e-government compliance service domains. Decision Support Systems, 47, 424-435. 
Lee, S. M., Lee D. and Schniederjans, M. J. 2011. Supply chain innovation and organizational performance in the healthcare industry. International Journal of Operations \& Production Management, 31(11), 1193-1214.

Lee, Y. and Kozar, K. A. 2006. Investigating the effect of website quality on e-business success: An analytic hierarchy process AHP approach. Decision Support Systems, 42, 13831401 .

Lin, C., Huang, Y.-A., Jalleh, G., Liu, Y.-X. and Tung, M.-L., 2010. AN EXPLORATORY STUDY OF FACTORS AFFECTING ADOPTION AND IMPLEMENTATION OF B2B ECOMMERCE IN AUSTRALIAN HEALTH CARE ORGANIZATIONS, International Journal of Electronic Commerce Studies, Vol. 1, No. 2 , pp.77-96.

Luk, S. C. Y. 2009. The impact of leadership and stakeholders on the success/failure of egovernment service: Using the case study of e-stamping service in Hong Kong. Government Information Quarterly, 26, 594-604.

Lv, W. 2010. The blue sea of medical e-commerce. Journal of Internet Weekly, 22.

Martilla, J. and James J. 1977. Importance - Performance Analysis. Journal of Marketing, 14, 77-79.

Ministry of Commerce of the people's Republic of China (MOFCOM) 2011. National pharmaceutical distribution industry Development Plan (2011 - 2015), http://www.mofcom.gov. cn/aarticle/ae/ai/201105/20110507534948.html?2413853418=4211347993[Accessed November 2013].

National Development and Reform Commission of China (NDRC) and State Council Information Office (SCIO) 2007. E-commerce development " $11^{\text {th }} 5$-year" plan, National Development and Reform Commission of China and State Council Information Office.

Nunnally, J. C. 1978. Psychometric theory (2nd ed.). New York: McGraw-Hill.

Pastor, D. A. (2013), "Validity: Factor Analysis", online at: www.jmu.edu/outreach/ wm_library/Validity_Factor_Analysis.pptx [August].

Pentina, I., Gammoh, B. S., Zhang, L. and Mallin, M. 2013. Drivers and Outcomes of Brand Relationship Quality in the Context of Online Social Networks, International Journal of Electronic Commerce, 17, 3, 63-86.

Perrigot, R. and Pénard, T. 2013. Determinants of E-Commerce Strategy in Franchising: A Resource-Based View, International Journal of Electronic Commerce, 17, 3, 109. 
Pramatari, K., Evgeniou, T. and Doukidis, G. 2009. Implementation of collaborative e-supply chain initiatives: an initial challenging and final success case from grocery retailing. Journal of Information Technology, 24, 269-281.

Ram, J., Corkindale, D. and Wu, M.-L. 2013. Implementation critical success factors (CSFs) for ERP: Do they contribute to implementation success and post-implementation performance? International Journal of Production Economics, 144(1), 157-174.

Ramanathan, R. 2010. E-commerce success criteria: determining which criteria count most. Electronic Commerce Research, 10, 191-208.

Ramanathan, R. 2012. A mathematical programming model for estimating the importance levels of performance criteria and an application in e-commerce. Expert Systems with Applications, 39: 2067-2072.

Sebora, T. C., Lee, S. M. and Sukasame, N. 2009. Critical success factors for e-commerce entrepreneurship: an empirical study of Thailand. Small Business Economics, 32, 303-316.

Shim, J. P., Shropshire, J., Park, S., Harris, H. and Campbell, N. 2007. Podcasting for elearning, communication, and delivery. Industrial Management \& Data Systems, 107 (4), 587600 .

SIG-Health 2012. CALL FOR PAPERS: Journal: Electronic Commerce Research and Applications Special issue on "eHealth and Healthcare Service Transformation." http://www.aissighealth.com/wordpress/?p=406 [Accessed January 2014].

Smith, A. D. and Correa, J. 2005. Value-added benefits of technology E-procurement and ecommerce related to the health care industry. International Journal of Health Care Quality Assurance, 18 (6), 458-473.

Stefani, A. and Xenos, M. 2008. E-commerce system quality assessment using a model based on ISO 9126 and Belief Networks. Software Quality Journal, 16, 107-129.

Sung, T. K. 2006. E-commerce critical success factors: East vs. West. Technological Forecasting \& Social Change, 73: 1161-1177.

Tomes, A. E. and Ng, S. C. P. 1995. Service quality in hospital care: the development of an in-patient questionnaire. International Journal of Health Care Quality Assurance, 8(3), 25-33.

van der Vaart, T. and van Donk, D. P. 2008. A critical review of survey-based research in supply chain integration. International Journal of Production Economics, 111(1), 42-55.

Wang, C., Wong, C. Y., Johansen, J., Qi, B. and Shen, S.-F. 2010. A comparison of supply chain decision-making factors between foreign and local retailers in Taiwan. The IUP Journal of Business Strategy, 7(4), 54-71. 
Wang, J. 2000. The nine development trends of the medical wholesalers (first part), http://www. cnm21.com/news/SHLW_058.HTM [Accessed November 2013].

Wang, T.-C. and Lin, Y.-L. 2009. Accurately predicting the success of B2B e-commerce in small and medium enterprises. Expert Systems with Applications, 36, 2750-2758.

Weathers, D. and Makienko, I. 2006. ASSESSING THE RELATIONSHIPS BETWEEN ETAIL SUCCESS AND PRODUCT AND WEB SITE FACTORS. JOURNAL OF INTERACTIVE MARKETING, 20 (2), 41-54.

Wee, Y. S. and Quazi, H. A. 2005. Development and validation of critical criteria of environmental management. Industrial Management and Data Systems, 105(1/2), 96, 19 pgs.

Wei, W. 2012. Domestic B2B operations revenue scale in the $1^{\text {st }}$ Quarter increases by $24.9 \%$ compared with previous year's, casting a new lowest growing rate. Beijing Business News, $4^{\text {th }}$ of May.

Wortzel, R., 1979. New life style determinants of women's food shopping behavior. Journal of Marketing, 43, 28-29.

Wu, J.-N., Zhong, W.-J. and Mei, S.-E. 2011. Application capability of e-business, e-business success, and organizational performance: Empirical evidence from China. Technological Forecasting \& Social Change, 78, 1412-1425.

Wu, W.-Y., Chiang C.-Y., Wu Y.-J., Tu H.-J. 2004. The influencing criteria of commitment and business integration on supply chain management. Industrial Management and Data Systems, 104(3/4), 322.

Yang, C.-C. (2012) Assessing the moderating effect of innovation capability on the relationship between logistics service capability and firm performance for ocean freight forwarders, International Journal of Logistics Research and Applications: A Leading Journal of Supply Chain Management, 15(1), 53-69.

Yang, J., Wang, R., Zhang, R. and Li, L. 2011. Analysis of the investigation on the ecommerce application status at different regions in China, OBSERVATION E-BUSINESS JOURNAL, No. 11, 7-8.

Zhang, M. 2011. Medical e-commerce application is going for growth. China E-governmental Affairs Net, http://www.e-gov.org.cn/dianzishangwu/hangyedianzishangwu/201110/ 123491.html [August 2012].

Zheng, M. 2012. Survival environment of B2B is changing dramatically. Chinese enterprises e-commerce net, http://www.ccecw.com/news/detail.asp?id=6377 [August 2012]. 
